\title{
PERFORMANCE AND EMISSIONS OF DIESEL ENGINE OPERATING ON BIODIESEL AND BUTANOL BLENDS
}

\author{
Tomas Mickevicius, Stasys Slavinskas, Gvidonas Labeckas \\ Vytautas Magnus University, Lithuania \\ tomas.mickevicius1@vdu.lt, stasys.slavinskas@vdu.lt, gvidonas.labeckas@vdu.lt
}

\begin{abstract}
The paper presents the experimental test results reflecting the comparative changes in the performance efficiency and emissions of the exhaust of a normally aspirated, four-stroke, single-cylinder, air-cooled diesel engine F1L511 occurring due to its transition from neat rapeseed oil biodiesel to operation on renewable fuel blends prepared by mixing in various proportion (by volume) rapeseed methyl ester (RME) and butanol (B). In contrast to previous works, the undertaken investigation was performed with totally renewable binary liquid fuel blends. The purpose of the research was to reduce the production of both exhaust smoke and NOx emissions with respect to neat biodiesel due to potentially improved homogeneity of combustible mixture and particulate matter emissions benefits suggested by the higher oxygen content $(21.62 \mathrm{wt} \%)$ and the relatively lower carbonto-hydrogen ratio (4.8) of butanol. The three renewable fuel blends B5, B10 and B15 were prepared by mixing 95 vol. \% RME/5 vol. \% B, 90 vol. \% RME/10 \% B and 85vol. \% RME/15vol. \% B, respectively. It was found that the brake specific fuel consumption for the tested biodiesel-butanol fuel blends was always higher than that measured under the same operating conditions with neat biodiesel. The lowest level of carbon monoxide emissions (CO) was also measured with the same biofuel blend B15 at medium (50\% of full) load. While the production of maximum $\mathrm{NO}_{\mathrm{x}}$ emissions from combustion of blend $\mathrm{B} 15$ was $0.6 \%$ lower than that experienced with neat biodiesel under the same test conditions. It is important to note that the lower $\mathrm{NO}_{\mathrm{x}}$ emissions have been accompanied by the lower smoke opacity from combustion of the most butanol-oxygenated fuel blend B15. Thus, the most problematic issue related with the reduction of both the $\mathrm{NO}_{\mathrm{x}}$ emissions and the smoke opacity (PM) can be solved quite easy by using for diesel engine powering totally renewable biodiesel-butanol fuel blends.
\end{abstract}

Keywords: diesel engine, rapeseed oil biodiesel, butanol, engine efficiency, brake specific fuel consumption, emissions, smoke opacity.

\section{Introduction}

Petroleum depletion, unstable price of petroleum products and stricter environmental protection requirements keep attracting more and more attention to renewable energy sources. The production and use of biofuel is one of the approaches to renewable energy. The constantly growing number of vehicles increases the consumption of mineral fuel and is a major source of environmental pollution. These economic and ecological reasons motivate people to try and solve the problems by using alternative and renewable fuel in internal combustion engines more efficiently. It is important to note that the physical and chemical properties of alternative fuel are largely different from those of traditional fuel. Thus, having replaced mineral fuel with biofuel the engine performance indicators most often change and are not optimal [1].

The main reason for using of biofuels in diesel engines is to lower greenhouse gas emissions, reduce global warming, promote rural development, and create new works in a global agricultural market. A wide use of renewable biofuels in agricultural and transport sectors seeks to increase energy independence and reduce consumer reliance on imported fossil fuels. Detailed analysis of the reasons leading to climate change, negotiations on reduction of carbon emissions and development of solutions for a gradual switch to renewable energy systems is provided in [2]. A lot of research and development is done to adapt neat RME, blended with diesel fuel and biofuels produced from renewables of various origins for diesel engines powering [3]. Using of renewable, oxygenated and sulphur-free fuels in internal combustion engines in a neat for more in blends with traditional diesel fuel saves fossil-fuel energy resources and makes less harm to the environment. 1-Butanol, also known as n-butanol, has a straight-chain structure with a hydroxyl group at the terminal carbon, and it has wide industrial applications. Butanol has attracted attention as an alternative biofuel because of its various advantages over other biofuels. The advances in butanol production were recently introduced to improve genetic modification of butanol-producing strains, and fermentation technology of butanol [4]. Moreover, the use of bio-based products in fuels is a strategic government resolution in most European countries [5]. The analysis of other investigations of fuel chemical parameters shows that from an engine-critical 
characteristics perspective butanol - hydrogenated vegetable oil - diesel blends are a potential solution [6].

Normal butanol $\left(\mathrm{C}_{4} \mathrm{H}_{9} \mathrm{OH}-74.0 \mathrm{~g} \cdot \mathrm{mol}^{-1}\right)$ is an alcoholic-origin colourless liquid with a harsh fusel with banana odour, which possesses $21.58 \mathrm{wt}$. \% of fuel-bound oxygen and differs as having low flash point of $28.9^{\circ} \mathrm{C}$ and the boiling point of $117.7^{\circ} \mathrm{C}$ at $760 \mathrm{~mm} \mathrm{Hg}$. On the one hand, n-butanol added to commercial diesel fuel reduces density, viscosity, $\mathrm{C} / \mathrm{H}$ atom ratio and provides fuel-bound oxygen that along with good evaporative properties improves both the air and fuel vapours mixing rate and the combustion of fuel blend leading to more environment friendly exhaust. On the other hand, the presence of a lighter and oxygenated n-butanol reduces the cetane number, net heating value and thus mass of the fuel consumed per unit of energy developed by an engine. The lower cetane number (chemical effect) of the bio-alcohols causes ignition delays and displacement-delay of the HRR diagram, while the little higher cetane number does not cause any discernible displacement-advance of the HRR diagram [7].

The sensitive interaction between advantages and disadvantages properties of $n$-butanol added to diesel fuel may lead to ambiguous development trends in combustion, heat release rate and engine out emissions [8]. The influence of autoignition of blends of $n$-butanol and ethanol with diesel or biodiesel fuels in a constant-volume combustion chamber was demonstrated in the experiment. The results showed that the increase of alcohol content in diesel or biodiesel, led to an increase in autoignition times. Such increase was not linear, but sharper for high alcohol contents, and was higher with ethanol than with butanol. For butanol blends, the increase in delay time was very similar when diesel or biodiesel were used. The maximum combustion pressure decreases as the alcohol content was increased, especially in the case of ethanol, as consequence of energy, chemical and dilution effects [9].

When using butanol diesel blend, it was found that soot emissions could be reduced significantly, while carbon monoxide (CO) and hydrocarbon ( $\mathrm{HCs}$ ) emissions, and NOx emissions were reduced or slightly increased under various operating conditions $[10,11]$. Wei et al. investigate compared effects of biodiesel-ethanol (BE) and biodiesel-n-butanol $(\mathrm{BBu})$ blends on combustion, performance and emissions of a direct-injection diesel engine. Experiments were conducted on BE5 (5\% ethanol and $95 \%$ biodiesel, v/v), BE10, BE15, BBu5, BBu10 and BBu15, at five engine loads and at $1800 \mathrm{rpm}$. They found that blended fuels had adverse effects on the engine performance, especially at low load, with the BE blends having more adverse effects than the BBu blends. Moreover, on average of the five engine loads, the $\mathrm{BBu}$ and $\mathrm{BE}$ blends increase $\mathrm{CO}$ emission by $13.7 \%$ and $22.8 \%$ and $\mathrm{HC}$ emission by $5.6 \%$ and $29.2 \%$, respectively; but reduce $\mathrm{NO}_{\mathrm{x}}$ emission by $6.5 \%$ and $28.0 \%$, particle mass concentration by $20.7 \%$ and $20.6 \%$ and particle number concentration by $22 \%$ and $21 \%$, respectively. Overall, the $\mathrm{BE}$ blends are more effective in reducing particulate and $\mathrm{NO}_{\mathrm{x}}$ emissions, but the $\mathrm{BBu}$ blends would lead to less increase in $\mathrm{CO}$ and $\mathrm{HC}$ emissions [12].

A study conducted a comparative analysis of fuel properties, performance, emissions and combustion characteristics of biodiesel produced from waste cooking oil (B100), along with a binary blend of biodiesel-diesel (B20) and ternary blends of biodiesel-diesel-butanol as substitutions to diesel fuel. Although biodiesel and n-butanol have some negative impacts on the engine performance parameters, they generally positively affect the exhaust emission parameters compared to euro diesel. Addition of n-butanol decreased some of the fuel thermo-physical properties, such as density, viscosity and flash point. The average decreases in the brake power when n-butanol was added were $6.17 \%, 7.49 \%$ and $11 \%$, respectively, coupled with increases in specific fuel consumption of $6.25 \%$, $8.96 \%$ and $14.29 \%$, respectively. The addition of n-butanol decreased exhaust gas temperatures, CO, $\mathrm{HC}, \mathrm{NO}$ and smoke emissions [13].

The purpose of the research was to reduce the production of both exhaust smoke and $\mathrm{NO}_{\mathrm{x}}$ emissions with respect to neat biodiesel due to potentially improved homogeneity of combustible mixture and particulate matter emissions benefits suggested by the higher oxygen content $(21.58 \mathrm{wt} \%)$ and the relatively lower carbon-to-hydrogen ratio (4.8) of butanol.

\section{Materials and methods}

Experimental research was carried out in the fuel equipment-testing laboratory of the Power and Transport Machinery Engineering Institute at the Faculty of Agricultural Engineering of the Vytautas Magnus University - Agricultural Academy. A for stroke, one cylinder, direct injection, air cooled 
"ORUVA FL 511" diesel engine was used for these experiments. The technical characteristics of the experimental engine are listed in Table 1.

Load characteristics of the engine were taken when operating at gradually increasing load and constant engine speed of $2000 \mathrm{rpm}$, at which the engine maximum torque develops.

Table 1

Engine FL 511 specifications

\begin{tabular}{|l|l|}
\hline \multicolumn{1}{|c|}{ Parameter } & \multicolumn{1}{c|}{ Value } \\
\hline Type & Deutz FL 511 \\
\hline Number of strokes & 4 stroke \\
\hline Number of cylinders & Single-cylinder \\
\hline Bore, $\mathrm{mm}$ & 100 \\
\hline Stroke, $\mathrm{mm}$ & 105 \\
\hline Displacement volume, $\mathrm{cm}^{3}$ & 825 \\
\hline Compression ratio & 17 \\
\hline Injection timing advance in CADs before TDC & $24^{\mathrm{o}}$ \\
\hline Maximum power (at 3000 rpm), kW & $12.8 \pm 5 \%$ \\
\hline Injection pressure, bar & $175 \pm 5 \mathrm{bar}$ \\
\hline Specific fuel consumption, $\mathrm{g} \cdot(\mathrm{kWh})^{-1}$ & $255 \pm 5 \%$ \\
\hline Rated speed, rpm & 3000 \\
\hline Engine weight, kg 135 & 135 \\
\hline
\end{tabular}

The test results are reflecting the comparative changes in the performance efficiency and emissions of the exhaust occurring due to its transition from neat rapeseed oil biodiesel to operation on renewable fuel blends prepared by mixing in various proportion (by volume) rapeseed methyl ester (RME) and butanol (B). In contrast to previous works, the undertaken investigation was performed with totally renewable binary liquid fuel blends. The three renewable fuel blends B5, B10 and B15 were prepared by mixing 95vol \% RME/5vol \% B, 90vol \% RME/10 \% B and 85vol \% RME/15vol \% $\mathrm{B}$, respectively. The properties of the tested fuels and their blends are presented in Table 2 .

Table 2

\section{Chemical and physical properties of RME and n-butanol}

\begin{tabular}{|c|c|c|c|}
\hline Property parameters & Fuel test methods & $\begin{array}{l}\text { Rapeseed oil } \\
\text { biodiesel (B) }\end{array}$ & $\begin{array}{c}\text { N-butanol } \\
\text { (Bu) }\end{array}$ \\
\hline Density at $15^{\circ} \mathrm{C}, \mathrm{kg} \cdot \mathrm{m}^{-3}$ & EN ISO 12185:1999 & 884.7 & 810 \\
\hline Kinematic viscosity, $\mathrm{mm}^{2} \cdot \mathrm{s}^{-1}$ & $\begin{array}{c}\text { EN ISO } 3104+\mathrm{AC}: 2000 \\
\text { at } 40^{\circ} \mathrm{C}\end{array}$ & 4.8 & 2.63 \\
\hline $\begin{array}{l}\text { Lubricity (HFRR), wear scar diameter } \\
\text { (wsd 1.4) at } 60^{\circ} \mathrm{C}, \mu \mathrm{m}\end{array}$ & EN ISO 12156-1 & 205 & 591 \\
\hline Flash point, open cup, ${ }^{\circ} \mathrm{C}$ & EN ISO 2719:2000 & 168 & 35 \\
\hline Initial/final boiling points, ${ }^{\circ} \mathrm{C}$ & EN ISO 3405:2011 & $346 / 366$ & 117.7 \\
\hline Auto-ignition temperature ${ }^{\circ} \mathrm{C}$ & - & $\sim 342$ & $\sim 343$ \\
\hline Cetane number & EN ISO 5165:1999 & 53.4 & 25 \\
\hline Oxygen content, $\max$ wt $\%$ & - & 10.9 & 21.62 \\
\hline Carbon-to-hydrogen ratio $(\mathrm{C} / \mathrm{H})$ & - & 6.49 & 4.8 \\
\hline Stoichiometric air/fuel ratio, $\mathrm{kg} \cdot \mathrm{kg}^{-1}$ & - & 12.62 & 11.12 \\
\hline Net heating value, $\mathrm{MJ} \cdot \mathrm{kg}^{-1}$ & EN ISO 8217:2012 & 37.23 & 33.08 \\
\hline
\end{tabular}

The torque of an engine was measured with a magnetic powder brake dynamometer PT40M $(0-$ $60 \mathrm{~N} \cdot \mathrm{m}$ ) with a definition rate of $\pm 0.5 \mathrm{~N} \cdot \mathrm{m}$ and the rotation speed with the mechanical tachometer (150-3000 rpm) with an accuracy of $\pm 0.5 \%$ of the measured value. The air mass consumption was measured with the turbine type gas meter CGT-02 $\left(10-100 \mathrm{~m}^{3} \cdot \mathrm{h}^{-1}\right)$ with an accuracy of $\pm 1 \%$ of the measured value, and the fuel mass consumption by using electronic scale SK-1000 with an accuracy of $\pm 0.5 \%$. 
Emissions of nitric oxide (NO), nitrogen dioxide $\left(\mathrm{NO}_{2}\right)$, carbon monoxide $(\mathrm{CO})$ in parts per million (ppm) and carbon dioxide $\left(\mathrm{CO}_{2}\right)$ in vol \% were measured with electrochemical cells installed in a Testo $350 \mathrm{XL}$ flue gas analyser. Total $\mathrm{NO}_{\mathrm{x}}$ emissions were determined as a sum of both $\mathrm{NO}$ and $\mathrm{NO}_{2}$ pollutants with an accuracy of $\pm 5 \mathrm{ppm}$. Exhaust smoke was measured with a Bosch RTT 110 opacity meter with an accuracy of $\pm 0.1 \%$ in a scale range of $0-100 \%$.

To improve reliability of the measured data the tests have been repeated no less than three times.

\section{Results and discussion}

Changes in the combustion process have influence on measurement of the engine economy. The analysis of Fig. 1 shows that when the engine is running on pure biodiesel at low load, the fuel consumption per hour $\left(B_{d}\right)$ and brake specific fuel consumption $(b s f c)$ are a lower compared to the engine running on biofuel blends.
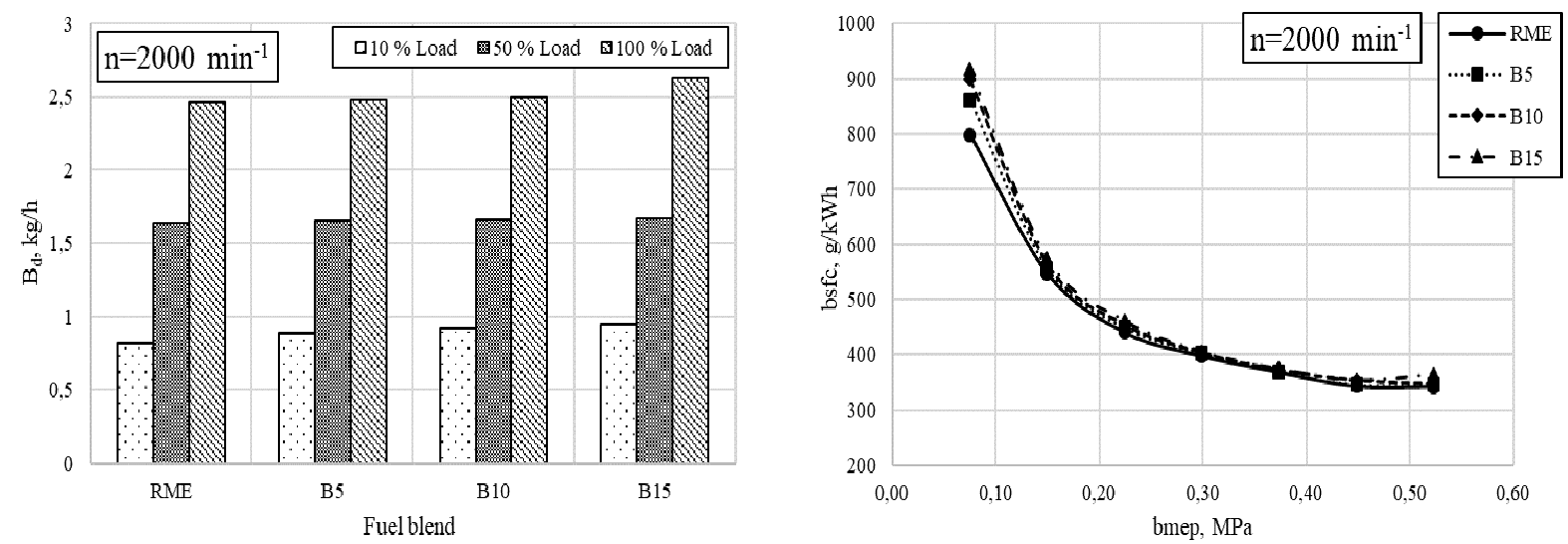

Fig. 1. Fuel consumption per hour $\left(B_{d}\right)$ and brake specific fuel consumption (bsfc) as a function of engine load at $2000 \mathrm{~min}^{-1}$

When the engine was running on biofuel blends B5-B15, the brake mean fuel consumption was increased by $7.8-14.8 \%$, respectively. When the engine load was raised to average, the brake mean fuel consumption of biofuel blends B5-B15 increased by 1.9-4.7\% respectively, in comparison with the engine running on pure biodiesel (RME). At full engine load, the break mean fuel consumption of biofuel blends B5-B15 goes up by 1.0-6.5 \%. The increased brake mean fuel consumption of biofuel blends B5-B15 may be attributed reasonably to the lower net heating value of butanol-biodiesel blends.

Columns of the brake specific fuel consumption $(b s f c)$ in $\mathrm{g} \cdot(\mathrm{kWh})^{-1}$ as a function of engine load (bmep) obtained during operation with RME fuel and RME-n-butanol fuel blends at speed of $2000 \mathrm{rpm}$ have been superimposed as shown in Fig. 1. As obvious from the figure, the $b s f c$ decreased with the increasing load to the value that depends on the engine load, speed, and fuel blend used sustaining at the highest level for the most oxygenated and thus less calorific blends. The lowest brake specific fuel consumption of $343.1 \mathrm{~g} \cdot(\mathrm{kWh})^{-1}$ was obtained for biodiesel fuel. The $b s f c$ gradually increased to $345.4(0.7 \%), 347.8(1.4 \%)$ and $365.6 \mathrm{~g} \cdot(\mathrm{kWh})^{-1}(6.6 \%)$ against the respective value of biodiesel fuel due to lower heating value of oxygenated fuel blends B5, B10 and B15.

When the engine operates on biofuel blend B15 at the full load, the brake thermal efficiency decreased by $4.7 \%$ (Fig. 2). The largest decrease of the brake thermal efficiency was monitored at the low engine loads. At low load the engine brake thermal efficiency decreases by $7.2-12.9 \%$ in comparison with the engine running on pure biodiesel fuel.

The NOx production depends on the ignition delay time and the amount of the fuel premixed for rapid combustion, maximum heat release rate, pressure inside the cylinder, and adiabatic flame temperature. The total emission of nitrogen oxides normally scales up when the load of the engine increases (Fig. 2). When the engine is running at the full load, using of oxygenated biofuel blends B5, $\mathrm{B} 10$ and $\mathrm{B} 15$ the total emissions of nitrogen oxides decreased by 3.0 to $1.0 \%$, respectively. The decrease in total emission of nitrogen oxides can be explained by the lower gas pressure and temperature in the cylinder as the combustion and heat release processes moved towards the direction 
of the expansion stroke. The pressure and temperature of the gas burning in a large volume of the cylinder are lower, which, in turn, conditions the lower degree of nitrogen oxides emission.

Smoke of the exhaust rising up from the engine running on biodiesel fuel and biofuel blends B5B15 is presented in Fig. 3. At low load, the higher smoke of the exhaust is produced by biofuel blend B15. At medium engine load, the smoke opacity remained lower in case of using all biofuel blends. When the engine was running on biofuel blend B10 at higher load, the smoke opacity decreased by $28.4 \%$, compared to the cases of using pure biodiesel fuel.
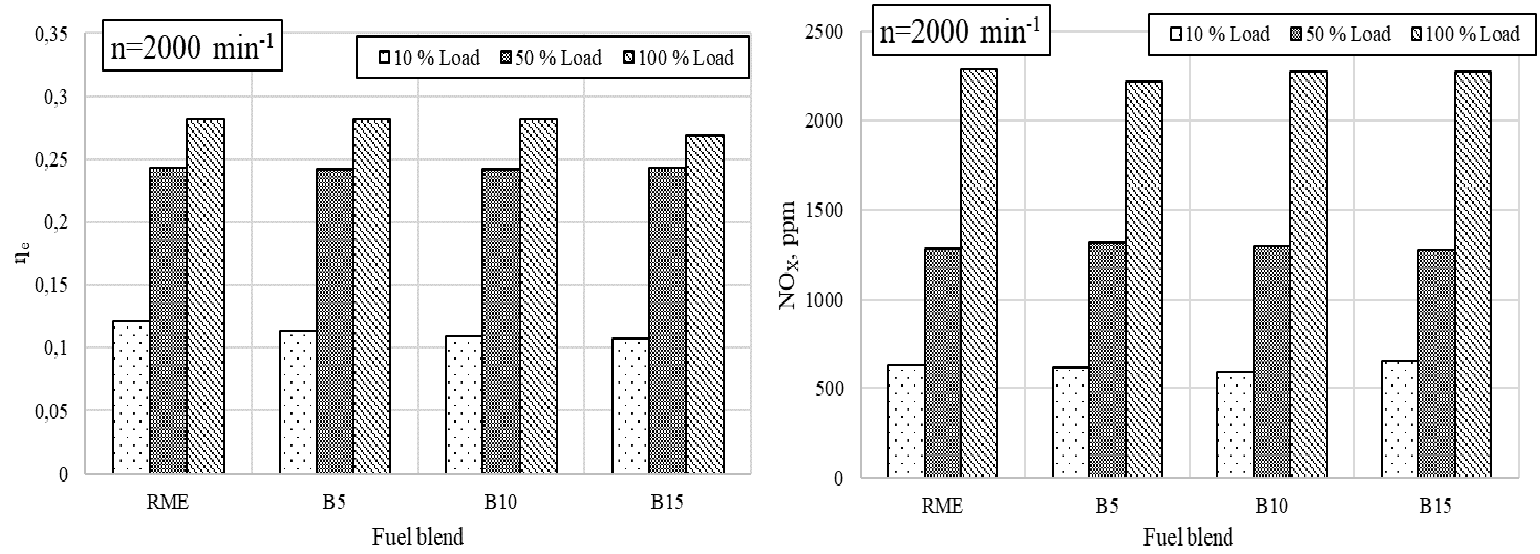

Fig. 2. Brake thermal efficiency $\left(\eta_{e}\right)$ and nitrogen oxide $\left(\mathbf{N O}_{\mathbf{x}}\right)$ as a function of engine load at $2000 \mathrm{~min}^{-1}$
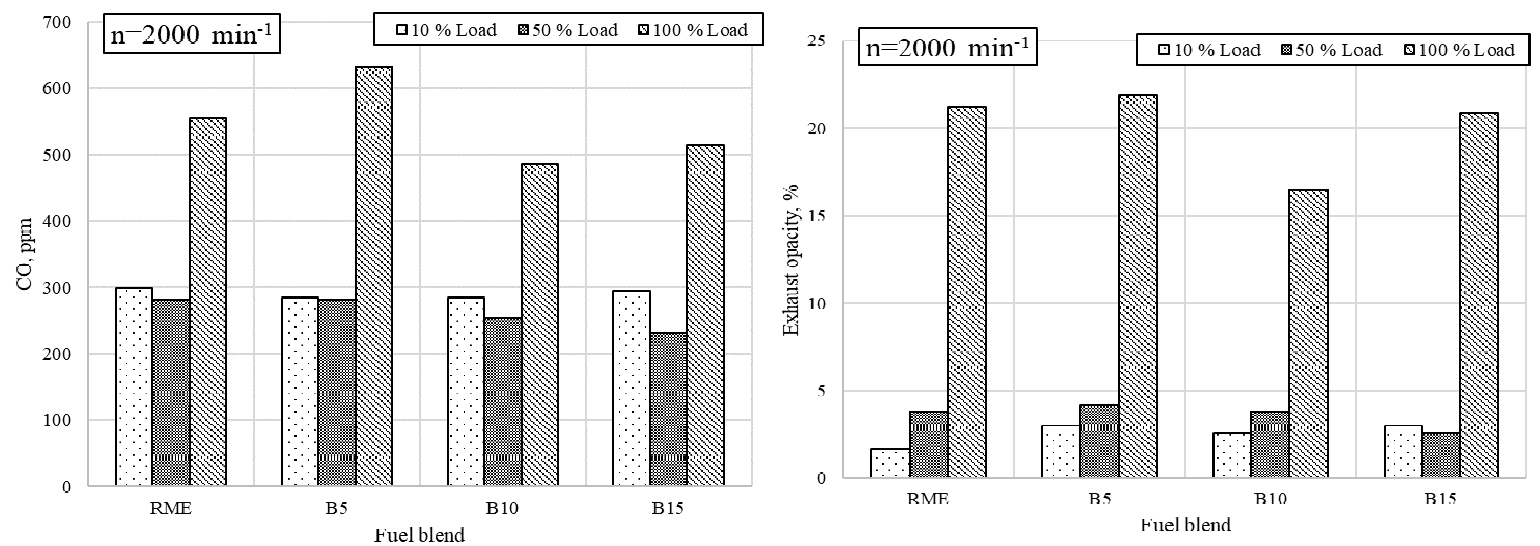

Fig. 3. Dependencies of carbon monoxide (CO) and smoke opacity of the exhaust on engine load at $2000 \mathrm{~min}^{-1}$

The production of $\mathrm{CO}$ emissions depends on the engine load, speed and the availability of airborn oxygen in the cylinder. When the engine was running with relatively low load, the emission of carbon monoxide produced from biofuel blend B5-B15 was lower than that of pure biodiesel fuel (Fig. 3). Using biofuel blends B5, B10 and B15, the emission of carbon monoxide decreases by $5.2 \%$, $5.3 \%$ and $1.7 \%$, respectively. After the engine load increased, the situation essentially changed. In case of full engine load and use of biofuel blends B10 and B15, the emission of carbon monoxide decreases by $14.1 \%$ and $7.9 \%$, respectively. At the same load and use of biofuel, blend B5, the CO emission increased by $14 \%$ in comparison to the engine running on pure biodiesel fuel. The increase in carbon monoxide emission may be initiated by the lower pressure and temperature in the combustion chamber.

\section{Conclusions}

1. The brake mean fuel consumption of biofuel blends over the entire range of load was higher. When operating on biofuel blends B5, B10 and B15 at full load, the break mean fuel consumption increased by $1.0 \%, 1.4 \%$ and $6.5 \%$ respectively, compared to pure biodiesel fuel. 
2. When the biofuel blend B15 was used in the engine running at the full load, the break thermal efficiency was lower $4.7 \%$ compared by the pure biodiesel fuel.

3. The higher total emissions (2290 ppm) of nitrogen oxides were measured from the engine running on pure biodiesel fuel at the full engine load.

4. When operating on biofuel blend B5, B10 and B15 at the medium load, the carbon monoxide emissions decreased by $7.8 \%, 19.4 \%$, and $33.3 \%$, respectively, compared to pure biodiesel fuel.

5. The smoke opacity of the engine operating on biofuel blends B5, B10 and B15 at the average engine load was reduced by $7.8 \%, 22.2 \%$ and $44.7 \%$, respectively, compared to the engine running on pure biodiesel fuel.

\section{References}

[1] Labeckas G., Slavinskas S. The effect of rapeseed oil methyl ester on direct injection diesel engine performance and exhaust emissions. Energy conversion and Management, 2006, 47.13-14, pp. 1954-1967.

[2] Engels, Anita. Anthropogenic climate change: how to understand the weak links between scientific evidence, public perception, and low-carbon practices. Energy Emiss. Control Technol, 2016, 4, pp. 17-26.

[3] Labeckas G., Slavinskas S. Combustion phenomenon, performance and emissions of a diesel engine with aviation turbine JP-8 fuel and rapeseed biodiesel blends. Energy Conversion and Management, 2015, 105, pp. 216-229.

[4] Zheng J., Tashiro Y., Wang Q., \& Sonomoto K. Recent advances to improve fermentative butanol production: genetic engineering and fermentation technology. Journal of bioscience and bioengineering, 2015, 119.1, pp. 1-9.

[5] Iliev S. Comparison of ethanol, methanol and butanol blending with gasoline and relationship with engine performances and emissions. Annals of Daaam \& proceedings, 2018, 29.

[6] Zöldy M. Fuel Properties of Butanol-Hydrogenated Vegetable Oil Blends as a Diesel Extender Option for Internal Combustion Engines. Periodica Polytechnica Chemical Engineering, 2020, 64.2, pp. 205-212.

[7] Rakopoulos D. C., Rakopoulos C. D, Giakoumis. G. Impact of properties of vegetable oil, biodiesel, ethanol and n-butanol on the combustion and emissions of turbocharged HDDI diesel engine operating under steady and transient conditions. Fuel, 2015, 156, pp. 1-19.

[8] Labeckas G., Slavinskas S., Rudnicki J., \& Zadrąg R. The effect of oxygenated diesel-n-butanol fuel blends on combustion, performance, and exhaust emissions of a turbocharged CRDI diesel engine. Polish Maritime Research, 2018, 25.1, pp. 108-120.

[9] Lapuerta M., Hernández J. J., Fernández-Rodríguez D., \& Cova-Bonillo A. Autoignition of blends of n-butanol and ethanol with diesel or biodiesel fuels in a constant-volume combustion chamber. Energy, 2017, 118, pp. 613-621.

[10] Kumar S., Cho J. H., Park J., \& Moon I. Advances in diesel-alcohol blends and their effects on the performance and emissions of diesel engines. Renewable and Sustainable Energy Reviews, 2013, 22, pp. 46-72.

[11] Wu H., Nithyanandan K., Zhang J., Lin Y., Lee T. H., Chia-fon F. L., \& Zhang C. Impacts of Acetone-Butanol-Ethanol (ABE) ratio on spray and combustion characteristics of ABE-diesel blends. Applied Energy, 2015, 149, pp. 367-378.

[12] Wei L., Cheung C. S.; Ning Z. Effects of biodiesel-ethanol and biodiesel-butanol blends on the combustion, performance and emissions of a diesel engine. Energy, 2018, 155, pp. 957-970.

[13]Örs İ., Sarıkoç S., Atabani A. E., \& Ünalan, S. Experimental investigation of effects on performance, emissions and combustion parameters of biodiesel-diesel-butanol blends in a directinjection CI engine. Biofuels, 2020, 11.2, pp. 121-134. 